\title{
CORRELATION BETWEEN OSTEOCHONDRAL CHANGES DEPICTED BY MAGNETIC RESONANCE IMAGING AND DISEASE PROGRESSION
}

Andréa S. Doria, Maria Helena B. Kiss, Adriana M. Sallum, Ana Paola N. Lotito, Erica N. Naka, Cláudio C. de Castro and Giovanni G. Cerri

DORIA AS et al. - Correlation between osteochondral changes depicted by magnetic resonance imaging and disease progression.

Rev. Hosp. Clín. Fac. Med. S. Paulo 56(4):107-114, 2001.

Purpose: To determine the consequences of the chronic use of systemic corticosteroids in children with juvenile rheumatoid arthritis by means of evaluating osteochondral effects depicted by magnetic resonance imaging.

Patients and Methods: We reviewed clinical and magnetic resonance imaging findings in 69 children (72 knees) with juvenile rheumatoid arthritis. Two groups were studied. Group I: 34 (49.3\%) children had previous or current use of systemic corticotherapy (22 girls; 12 boys; mean age: 11.3 years; mean disease duration: 5.9 years; mean corticotherapy duration: 2.9 years; mean cumulative dose of previous corticosteroids: $5000 \mathrm{mg}$ ); Group II: 35 (50.7\%) children had no previous use of corticosteroids (27 girls; 8 boys; mean age: 11.7 years; mean disease duration: 5.3 years). The groups were compared statistically.

Results: In the group that had received corticotherapy (Group I), osteochondral abnormalities were significantly correlated to long-standing disease $(>3.5$ years; $\mathrm{p}<0.001)$. This correlation was not found in the group that had no previous history of corticotherapy (Group II). No correlations were established between median dose of corticosteroids and magnetic resonance imaging findings.

Conclusion: It is important to further investigate the long-term intra-articular effects of systemic corticotherapy to ensure that the side effects of the aggressive therapy will not be more harmful for the joints than the symptoms suffered over the natural course of the disease.

DESCRIPTORS: Systemic corticotherapy. Juvenile rheumatoid arthritis. Children. Knee. Magnetic resonance imaging.

Juvenile rheumatoid arthritis (JRA) is a relatively common childhood disease characterized by chronic arthritis ${ }^{1}$, with a prevalence in developed countries of approximately 1 in 1000 children $^{2}$. Synovitis is responsible for the development of synovial hypertrophy (pannus) that can erode articular cartilage and bone and invade the adjacent bone marrow space, leading to joint deformity and producing much of the morbidity and disability in the disease $^{3,4}$. For those children who do not respond to salicylates and nonsteroid anti-inflammatory drugs, corticosteroids and other immunosuppressive agents may be required for management of the disease.

Radiography does not provide information about the status of osteochondral structures before cartilage is damaged $^{5}$. On the other hand, magnetic resonance imaging (MRI) provides exquisite distinction of bone and soft tissue in the articular structures ${ }^{3-6}$ and is a highly sensitive tool for establishing the diagnosis of $\mathrm{JRA}^{7}$.

From the Division of Diagnostic Imaging of the Heart Institute and the Division of Pediatric Rheumatology, Hospital das Clínicas, Faculty of Medicine, University of São Paulo.
The systemic side effects of longterm corticotherapy in children are well-established ${ }^{8}$. To justify chronic use of corticotherapy, the therapy's benefits must offset not only the risks of the disease itself but also its own adverse side effects. Although there is little doubt that the use of systemic corticotherapy improves the signs and symptoms of rheumatoid arthritis in most patients, it is uncertain whether over long-term use it can produce more adverse effects on joints than other drug treatment regimens. Careful consideration of long-term systemic corticotherapy is mandatory not only 
because of its known systemic side effects, but also because of the drug-induced intra-articular changes.

This study investigates the MRI findings, rather than the traditionally used radiographic findings, in a crosssection of JRA patients with varying durations of the disease who had or not undergone previous corticotherapy. The purpose of our study was to establish correlations among the presence of synovial and osteochondral abnormalities demonstrated by MRI, disease activity at the time of exam, and previous and/or current systemic corticotherapy.

\section{PATIENTS AND METHODS}

Sixty-nine children with clinically proven JRA, according to the classification criteria of the American College of Rheumatology ${ }^{9}$ were selected for the study. Disease duration at the time of MRI performance ranged from 5 months to 14 years (mean: 5.6 years). Two groups of patients with JRA were analyzed. Group I included 34 (49.3\%) patients who had a previous or current history of corticotherapy. In this group, we analyzed 36 knees. Group II included $35(50.7 \%)$ patients who were using either no medication or drug therapy other than corticosteroids. We studied 36 knees in this group.

\section{Patient Characteristics}

In Group I, 22 (64.7\%) patients were girls and 12 (35.3\%) were boys. Their mean age was 11.3 (range: 4.817.1) years, mean disease duration was 5.9 years, mean duration of corticotherapy was 2.9 years, and median total dose of corticosteroids previously used was 5000 (range: 22540283) mg. Among Group I patients, $11(32.4 \%)$ presented clinical activity at the time of exam as defined by the presence of arthritis in any joint ${ }^{5}$. Twenty-two $(64.7 \%)$ patients had systemic disease, 10 (29.4\%) had polyarticular disease, and 2 (5.9\%) had pauciarticular disease.

In this group, clinical indication for use of systemic corticotherapy had been based on severe manifestations of the disease, including pericarditis, myocarditis, vasculitis, and hemophagocytic syndrome. The dose of corticosteroids was adjusted to the clinical and laboratory severity of disease. Group I was further subdivided according to duration of corticotherapy: Group IA had $\leq 1$ year corticotherapy and Group IB had $>1$ year. We also compared the results within each group between those patients with prolonged disease duration ( $>3.5$ years) and those with shorter duration of disease $(\leq 3.5$ years).

In Group II, there were 27 (77.1\%) girls and $8(22.9 \%)$ boys; their mean age was 11.7 (range: 2.6-20) years, and mean disease duration was 5.3 years. Among these children, 10 (28.6\%) presented clinically active disease. Eleven (31.4\%) patients had systemic disease, $9(25.7 \%)$ had polyarticular disease, and $15(42.9 \%)$ had pauciarticular disease.

\section{Magnetic Resonance Imaging (MRI)}

We performed MRI on the knees of all patients included in this study using a 1.5-T magnet, a whole volume extremity coil, and the imaging parameters listed in table 1. Gadolinium was injected intravenously at a dosage of $0.1 \mathrm{mmol} / \mathrm{kg}$. The images were evaluated independently by 2 experienced radiologists who were blinded to the clinical history or plain films and directed to evaluate: (1) the presence of synovial proliferation in the suprapatellar bursa-eg, synovial enhancement post-gadolinium; (2) the presence of osteochondral abnormalities-eg, subchondral cysts, marginal erosions, and/ or bone marrow edema; (3) both of the above findings, and (4) absence of depictable lesions.

\section{Statistical Analysis}

Correlations among MRI findings and (1) disease duration (ie, $\leq 3.5$ years

Table 1 - Pulse sequences used for analysis of MRI findings.

\begin{tabular}{|c|c|c|c|c|c|c|c|}
\hline Series & $\begin{array}{c}\mathrm{TR} \\
(\mathrm{ms})\end{array}$ & $\begin{array}{c}\mathrm{TE} \\
(\mathrm{ms})\end{array}$ & $\begin{array}{l}\text { Slice thickness/gap } \\
(\mathrm{mm})\end{array}$ & $\begin{array}{c}\text { Flip angle } \\
\left({ }^{0}\right)\end{array}$ & FOV & Matrix & $\begin{array}{l}\text { Time } \\
(\min )\end{array}$ \\
\hline Sagittal IW SE & 1800 & 20 & $4.0 / 0.4$ & 90 & 180 & $179 \times 256$ & 03:07 \\
\hline Sagittal T2 SE & 1800 & 85 & $4.0 / 0.4$ & 90 & 180 & $179 \times 256$ & 03:07 \\
\hline Coronal T1 SE & 25 & 20 & $4.0 / 0.0$ & 90 & 180 & $179 \times 256$ & $03: 18$ \\
\hline Coronal T2 FFE & 40 & 14 & $4.0 / 0.0$ & 10 & 180 & $179 \times 256$ & $01: 32$ \\
\hline Coronal T1 SE (post-gad.) & 525 & 20 & $4.0 / 0.0$ & 90 & 180 & $179 \times 256$ & $03: 18$ \\
\hline Sagittal T1 SE (post-gad.) & 525 & 20 & $4.0 / 0.4$ & 90 & 180 & $179 \times 256$ & $01: 52$ \\
\hline Axial T1 SE (post-gad.) & 525 & 20 & $4.0 / 0.4$ & 90 & 180 & $179 \times 256$ & $03: 22$ \\
\hline Axial T1 SPIR SE (post-gad.) & 525 & 20 & $4.0 / 0.4$ & 90 & 180 & $179 \times 256$ & 05:02 \\
\hline
\end{tabular}

$\mathrm{TR}=$ time repetition; $\mathrm{TE}=$ time echo $\mathrm{ms}=$ milliseconds $;$ min = minutes; post-gad. = post-gadolinium; $\mathrm{SE}=$ spin-echo; FOV = field-of-view; IW = intermediate-weighted; SPIR = spectral presaturation with inversion recovery 
or $>3.5$ years), (2) clinical activity of disease, (3) previous use of corticosteroids, (4) duration of corticotherapy, (5) dose of systemic corticosteroids, and (6) type of osteochondral changes were analyzed using the Fisher's exact test $(2 \text {-tail })^{10}$, with a $\mathrm{p}$ value $<0.05$ indicating statistical significance.

\section{RESULTS}

In Group I patient's joints ( $\mathrm{n} 1=$ number of joints) with disease duration longer than 3.5 years $(\mathrm{n} 1=23)$, MRI depicted osteochondral changes both with $(\mathrm{n} 1=14)$ and without $(\mathrm{n} 1=3)$ associated synovial proliferation in 17 joints (Fig. 1 and Table 2). Four of these patients had clinically active disease. In Group II children with longstanding disease $(\mathrm{n} 1=21), 17$ patients demonstrated cartilaginous abnormalities both with $(\mathrm{n} 1=15)$ and without $(\mathrm{n} 1=2)$ associated synovial changes (Fig. 2 and Table 2). Eight of these children had clinically active disease.

Although the results between these two groups are comparable, significant differences in MRI findings with regard to osteochondral lesions and synovial enhancement in patients with long and short disease duration were demonstrated only in Group I ( $\mathrm{p}<0.001)$. In Group II, we did not find any significant relationship between disease duration (ie, $\leq 3.5$ years or $>3.5$ years) and the 4 parameters analyzed by MRI ( $\mathrm{p}=0.076)$, nor between the presence of osteochondral changes and clinical disease activity in any of the groups. However, we did find a significant difference between MRI findings of osteochondral abnormalities according to disease duration $(\mathrm{p}<0.001)$ (Table 2) in Group I patients. In this group $(\mathrm{n} 1=36)$, among the 18 patients in whom MRI demonstrated osteochondral lesions, changes were more often associated with synovial prolif- eration (Fig. 1A) than seen as isolated findings (Fig. 3A). Fifteen of these children demonstrated such proliferation $(\mathrm{p}<0.001)$ (Table 2).

When we analyzed results according to disease duration for children with > 3.5 years of disease in Group I patients $(\mathrm{n} 1=23)$, presence of osteochondral lesions associated with synovial proliferation was the most com-
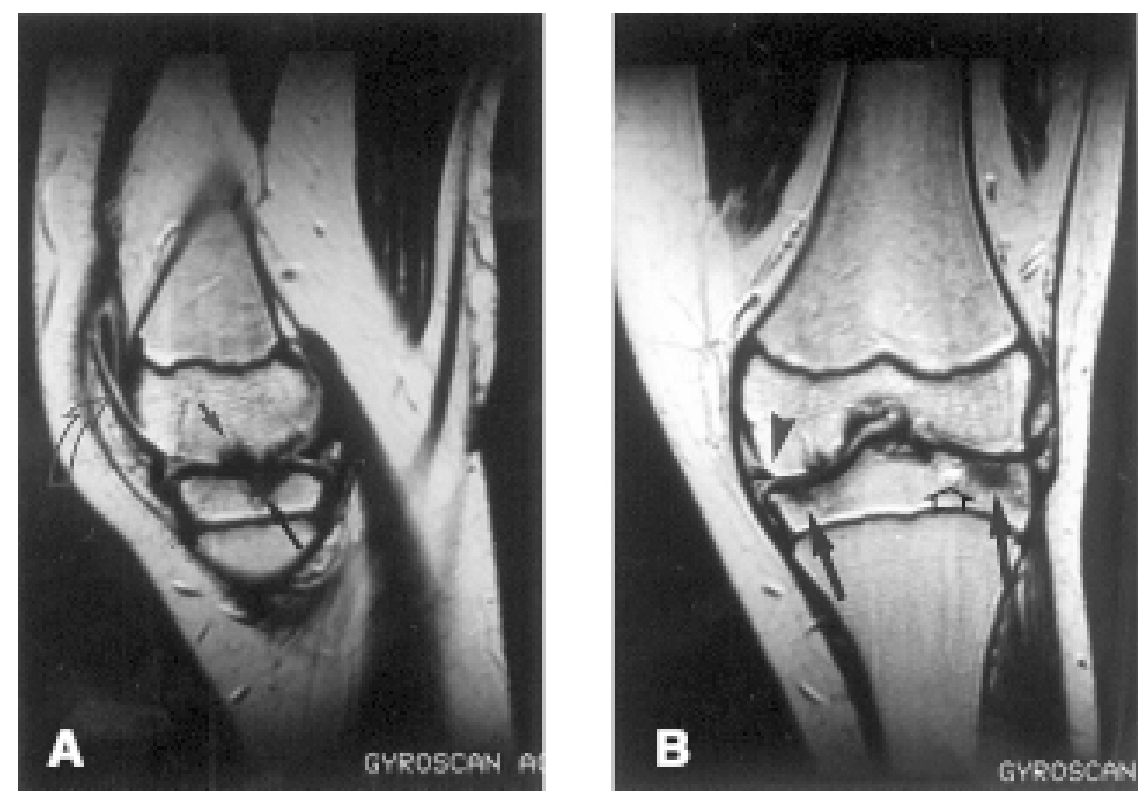

Figure 1 - An example of longstanding disease (12-year duration) in a 17-year-old boy with a previous 5.6-year use of systemic corticotherapy, as represented by (A) a sagittal T1-weighted SE image and (B) a coronal T1-weighted SE image obtained after gadolinium administration. Note the osteochondral abnormalities demonstrated by subchondral cysts (black arrows), bone erosion (black arrowhead), and zones of bone marrow hyperemia within the epiphysis (open arrow) associated with thickening of the synovial lining of the suprapatellar bursa (curved arrow).

Table 2 - Correlations between MRI findings and disease duration in joints of Group I and II patients.

\begin{tabular}{|c|c|c|c|}
\hline \multirow[b]{2}{*}{ MRI Findings (Group I) } & \multicolumn{2}{|c|}{ Disease Duration } & \multirow[b]{2}{*}{ Total } \\
\hline & $\leq 3.5$ years & $>3.5$ years & \\
\hline Osteochondral lesions & $0(0 \%)$ & $3(100 \%)$ & 3 \\
\hline Synovial enhancement & $6(54.55 \%)$ & $5(45.45 \%)$ & 11 \\
\hline Synovial enhancement and osteochondral lesions & $1(6.67 \%)$ & $14(93.33 \%)$ & 15 \\
\hline No osteochondral/synovial pathologic findings & $6(85.71 \%)$ & $1(14.29 \%)$ & 7 \\
\hline Total (number of joints) & 13 & 23 & 36 \\
\hline \multirow[t]{2}{*}{ Fisher's exact test (2-tail) } & $\mathrm{p}<0.001$ & & \\
\hline & \multicolumn{2}{|c|}{ Disease duration } & \\
\hline MRI findings (Group II) & $\leq 3.5$ years & $>3.5$ years & Total \\
\hline Osteochondral lesions & $1(33.33 \%)$ & $2(66.67 \%)$ & 3 \\
\hline Synovial enhancement & $4(66.67 \%)$ & $2(33.33 \%)$ & 6 \\
\hline Synovial enhancement and osteochondral lesions & $5(25 \%)$ & $15(75 \%)$ & 20 \\
\hline No osteochondral/synovial pathologic findings & $5(71.43 \%)$ & $2(28.57 \%)$ & 7 \\
\hline Total (number of joints) & 15 & 21 & 36 \\
\hline Fisher's exact test (2-tail) & $\mathrm{p}=0.076$ & & \\
\hline
\end{tabular}



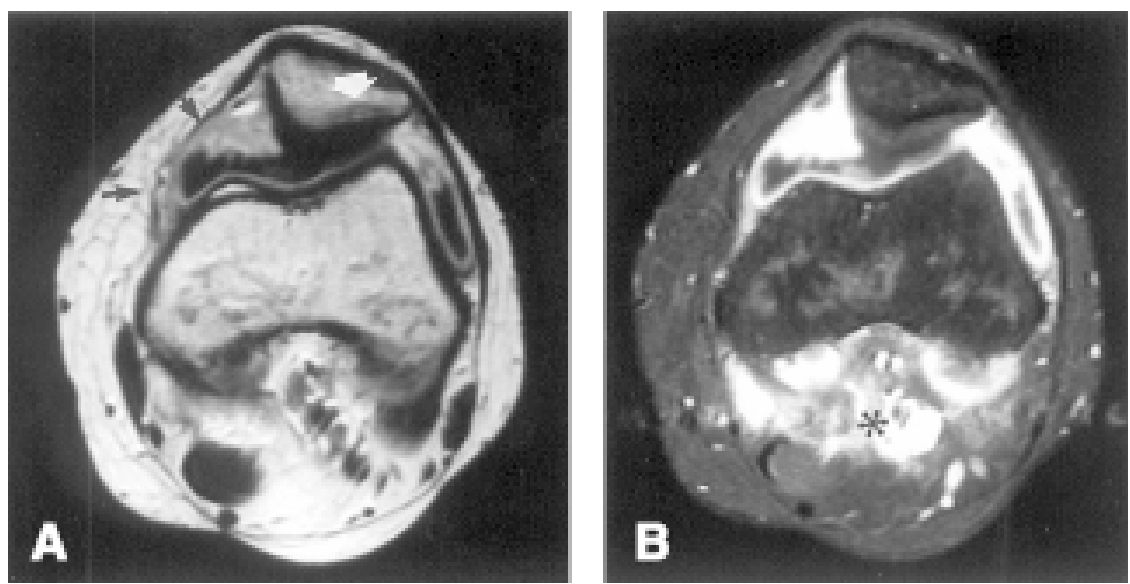

Figure 2 - Example of longstanding arthritis (12-year duration) in an 18-year-old girl with polyarticular JRA with no previous use of systemic corticotherapy, represented by post-gadolinium MRI images of (A) an axial T1-weighted SE and (B) an axial fat-suppressed, T1-weighted SE sequence. Note the corresponding appearance of enhancing synovium (black arrows) and subchondral cyst on patella (white arrow) in panel A. In the axial fat-suppressed, T1-weighted SE image, the full extension of the hypertrophied synovium is masked by surrounding enhanced vessels (asterisk). This example shows that the natural progression of disease, independently of concomitant systemic therapy, may lead to formation of subchondral cysts. This evidence suggests that other factors than corticotherapy use including natural progression of disease - may be responsible for osteochondral damage.
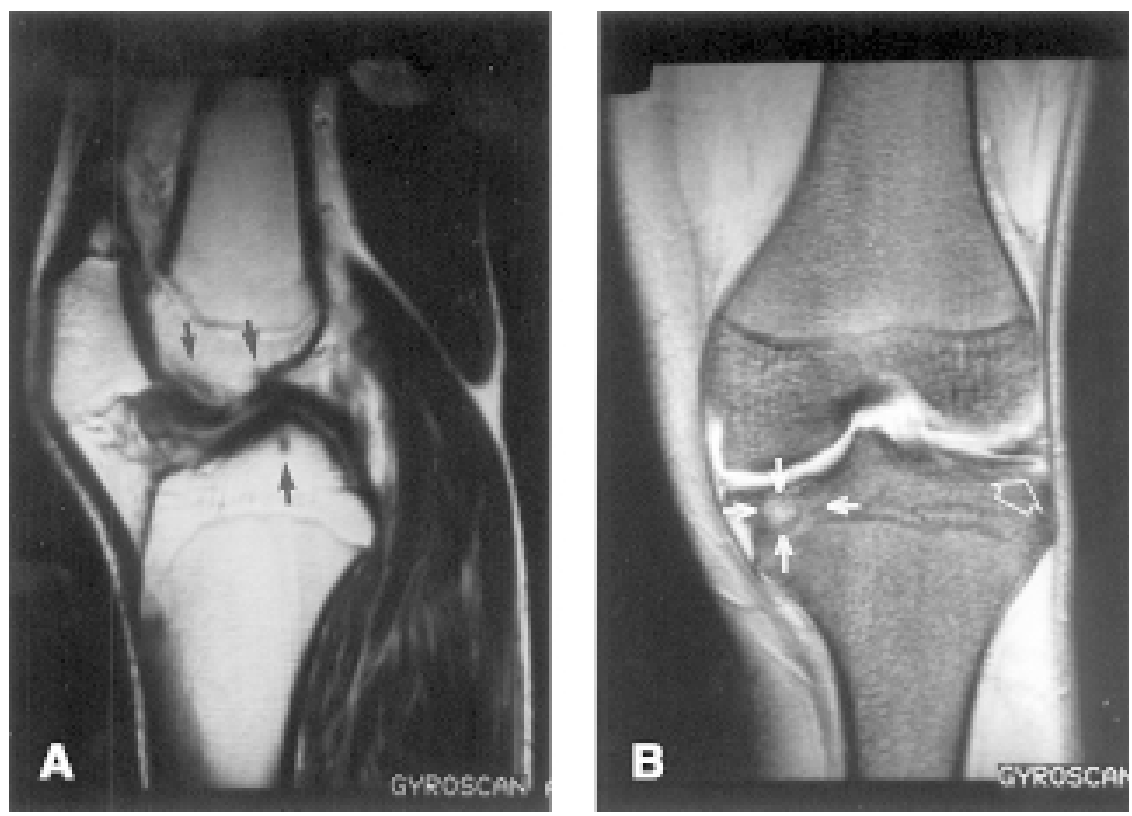

Figure 3 - Osteochondral abnormalities, without synovial enhancement, are seen in this 17-year-old boy with continuous use of systemic corticotherapy for 7 months in a longstanding course of the disease (14 years) represented by post-contrast MRI images of the (A) sagittal T1-weighted SE and (B) coronal T2-weighted FFE sequences. In Figure 3A, note the subchondral cysts (black arrows) that can be demonstrated within the femoral and tibial epiphysis. The coronal T2-weighted FFE sequence in Figure 3B underestimates the area of the subchondral cyst (white arrows), since the peripheral aspect of the cyst has the same signal intensity as adjacent bone marrow. On this sequence, bone marginal erosions are difficult to discern (open arrow). This case demonstrates that although both disease and corticotherapy duration in Group I may be responsible for the destructive changes in the knees, long disease duration (natural progression of disease) seems to play a more important role in the development of osteochondral abnormalities in JRA than long-term corticotherapy.

teroids for more than 1 year, as compared with children receiving corticosteroids for less than 1 year. In the group of patients using corticosteroids for $>1$ year $(\mathrm{n} 1=23)$, osteochondral changes were seen in 13 children, and in all 13 cases, synovial hypertrophy was also present. In the patients using corticotherapy for at least 1 year $(\mathrm{n} 1=$ 13), osteochondral changes were seen in 5 joints, in 3 as the only finding, and in 2 associated with synovial proliferation, $(\mathrm{p}=0.015)$ (Table 3).

No statistically significant differences were noted between MRI findings according to the total dose of systemic corticotherapy previously used in any of the Group I patients analyzed (n =33) $(\mathrm{p}=0.205)$ (Table 4). Three patients, each having 1 joint analyzed, were not included in this analysis because of inconclusive data from clinical history and follow-up.

Table 5 outlines relationships between types of osteochondral abnormalities and MRI findings. A strong relationship was obtained in Group I $(\mathrm{p}<0.0001)$ but not in Group II. The majority of cartilaginous lesions were seen along with synovial proliferation in both Group I $(\mathrm{n} 1=16)$ and Group II $(\mathrm{n} 1=20)$. The most common osteochondral findings were the association of bone erosions and subchondral cysts in Group I (n1 = 9) (Fig. 3B) and isolated bone erosions in Group II ( $\mathrm{n} 1=$ $15)$.

\section{DISCUSSION}

Because of its excellent soft tissue contrast, MRI allows detection of early articular changes ${ }^{5,6,11,12}$ and provides information for both diagnostic ${ }^{3,7,13}$ and therapeutic purposes ${ }^{14-19}$. Before the advent of MRI, radiography was the only noninvasive method available for direct visualization of bone changes in joints and was the "gold standard" modality for identification of progression in rheumatoid arthritis ${ }^{20-25}$. Since the 1950s, much concern has been expressed about the effects of medication used in this disease which has led to large multicenter trials, such as those comparing the effects of oral steroids 
to effects of aspirin ${ }^{26-31}$. As an example of such effects, adults treated with systemic or intra-articular corticosteroids have demonstrated disturbances of endogenous cortisol synthesis, including Cushing's syndrome ${ }^{32}$.

There are recent studies about the local effects of intra-articular injection of corticosteroids ${ }^{14-17,33}$, but few are about the intra-articular results following prolonged systemic corticotherapy.
In 1990, Wilske and Healey ${ }^{19}$ proposed an aggressive treatment plan for cases of destructive rheumatoid arthritis. Their study included the use of multiple medications, including oral steroids, and challenged the conventional treatment that employed a slow, stepwise addition of medications ${ }^{34-37}$. A few years earlier, Iannuzzi et al. ${ }^{38}$ found evidence through radiographic assessment that both cyclophospha-

Table 3 - Correlations between MRI findings and duration of systemic corticotherapy in the joints of Group I patients.

\begin{tabular}{|c|c|c|c|}
\hline \multirow[b]{2}{*}{ MR findings (CG) } & \multicolumn{2}{|c|}{ Systemic use duration } & \multirow[b]{2}{*}{ Total } \\
\hline & $\leq 1$ year & $>1$ year & \\
\hline Osteochondral lesions & $3(100 \%)$ & $0(0 \%)$ & 3 \\
\hline Synovial enhancement & $4(36.36 \%)$ & $7(63.64 \%)$ & 11 \\
\hline Synovial enhancement and osteochondral lesions & $2(13.33 \%)$ & $13(86.67 \%)$ & 15 \\
\hline No osteochondral/synovial pathologic findings & $4(57.14 \%)$ & $3(42.86 \%)$ & 7 \\
\hline $\begin{array}{l}\text { Total (number of joints) } \\
\text { Fisher's exact test (2-tail) }\end{array}$ & $\begin{array}{l}13 \\
\mathrm{p}=0.015\end{array}$ & 23 & 36 \\
\hline
\end{tabular}

Table 4 - Correlations between MRI findings and total dose of systemic corticotherapy used during treatment of JRA in the joints of Group I patients.

\begin{tabular}{|c|c|c|c|}
\hline \multirow{2}{*}{$\begin{array}{l}\text { Corticotherapy Group } \\
\text { MR findings }\end{array}$} & \multicolumn{3}{|c|}{$\begin{array}{l}\text { Cummulative dose of systemic } \\
\text { corticosteroids (mg) }\end{array}$} \\
\hline & $\leq \mathbf{5 0 0 0}$ & $>5000$ & Total \\
\hline Osteochondral lesions & $3(100 \%)$ & $0(0 \%)$ & 3 \\
\hline Synovial enhancement & $6(54.55 \%)$ & $5(45.45 \%)$ & 11 \\
\hline Synovial enhancement and osteochondral lesions & $4(30.77 \%)$ & $9(69.23 \%)$ & 13 \\
\hline No osteochondral/synovial pathologic findings & $3(50 \%)$ & $3(50 \%)$ & 6 \\
\hline Total (number of joints) & 16 & 17 & 33 \\
\hline Fisher's exact test (2-tail) & $\mathrm{p}=0.205$ & & \\
\hline
\end{tabular}

Frequency missing $=3$

mide and gold would retard the radiographic progression of joint destruction. Nevertheless, the long-term effects of prolonged corticotherapy are still not completely clear because of the consideration of confounding variables such as severity of disease that affects both steroid use and osteochondral damage.

In this study, we found significant relationships between the MRI findings, including presence of osteochondral abnormalities (subchondral cysts and/or bone erosions), and disease duration in Group I (children with previous history of corticotherapy); however, no such relationship was found for Group II (children with no previous history of corticotherapy). Prolonged use of systemic corticosteroids (>1 year) also seemed to be related to a higher degree of deleterious effects on the cartilage, although no significant relationship to the total dose of corticosteroids used during treatment was determined. Moreover, we found no evidence of a relationship between osteochondral changes depicted on MRI and disease activity at the time of MRI performance either for Group I or for Group II. The use of systemic corticotherapy in the group of patients with more aggressive disease suggested the possibility of an interaction be-

Table 5 - Correlation between types of osteochondral changes and MRI abnormalities in the joints of Group I and II patients.

\begin{tabular}{|c|c|c|c|c|c|}
\hline MR findings (Group I) & SC & $\mathbf{E r}+\mathrm{SC}$ & $\mathbf{E r}$ & Absence & Total \\
\hline Osteochondral lesions & $0(0 \%)$ & $1(50 \%)$ & $1(50 \%)$ & $0(0 \%)$ & 2 \\
\hline Synovial enhancement & $0(0 \%)$ & $0(0 \%)$ & $0(0 \%)$ & $11(100 \%)$ & 11 \\
\hline Synovial enhancement and osteochondral lesions & $2(12.5 \%)$ & $8(50 \%)$ & $5(31.25 \%)$ & $1(6.25 \%)$ & 16 \\
\hline No osteochondral/synovial pathologic findings & $0(0 \%)$ & $0(0 \%)$ & $0(0 \%)$ & $7(100 \%)$ & 7 \\
\hline Total (number of joints) & 2 & 9 & 6 & 19 & 36 \\
\hline Fisher's exact test (2-tail) & $\mathrm{p}<0.0001$ & & & & \\
\hline MR findings (Group II) & SC & $\mathbf{E r}+\mathbf{S C}$ & $\mathbf{E r}$ & Absence & Total \\
\hline Osteochondral lesions & $0(0 \%)$ & $0(0 \%)$ & $3(100 \%)$ & $0(0 \%)$ & 3 \\
\hline Synovial enhancement & $0(0 \%)$ & $0(0 \%)$ & $0(0 \%)$ & $6(100 \%)$ & 6 \\
\hline Synovial enhancement and osteochondral lesions & $0(0 \%)$ & $8(40 \%)$ & $12(60 \%)$ & $0(0 \%)$ & 20 \\
\hline No osteochondral/synovial pathologic findings & $0(0 \%)$ & $0(0 \%)$ & $0(0 \%)$ & $7(100 \%)$ & 7 \\
\hline Total (number of joints) & 0 & 8 & 15 & 13 & 36 \\
\hline Fisher's exact test (2-tail) & $\mathrm{p}=0.526$ & & & & \\
\hline
\end{tabular}

$\mathrm{SC}=$ subchondral cysts; $\mathrm{Er}+\mathrm{SC}=$ bone erosions associated to subchondral cysts; $\mathrm{Er}=$ bone erosions; Absence = no lesions 
tween the severity of disease and osteochondral abnormalities rather than between abnormalities and therapeutic medication. However, it was not possible to establish statistically significant relationships between presence or absence of lesions and previous use or lack of use of systemic corticotherapy, regardless of disease duration. Nevertheless, our results corroborate previous radiological studies ${ }^{39-41}$, providing the possibility that over the course of the disease more severe deformities in articular joints could be produced following treatment with corticosteroids. Because MRI allows identification of subtle cartilaginous abnormalities very early, we were able to show the abnormalities in an earlier period of disease than previous radiological studies have shown. A limitation of this and previous studies using radiographies is the difficulty to know whether patients receiving steroids were already at higher risk of developing osteochondral abnormalities, since they would belong to a more aggressive spectrum of JRA, which is bound to bias the results.

The goal of therapy for JRA is to retard clinical and radiographic joint degeneration, but the adverse systemic and intra-articular effects of long-term treatment should not outweigh the purpose of systemic therapy. Another point of concern is the disparity between the clinical improvement in patients following systemic medications and the worsening of radiographically diagnosed damage. Our study evaluated children with JRA who received short- and long-term systemic corticosteroids, comparing them with a noncorticotherapy group to determine the osteochondral abnormalities in the knees according to duration of immunosuppressive therapy. We did not consider other concurrent or confounding variables, such as combined therapy, that could influence the progression of articular damage in either Group I or Group II.

Numerous questions raised by this study reflect the problem of distinguishing between effects of disease and effects of corticosteroids. Does systemic corticotherapy produce additional and different changes than those caused by the disease? Were our results a consequence of the fact that the patients given corticotherapy already had more destructive disease? Do these osteochondral abnormalities also develop in non-rheumatoid experimental models given long-term systemic corticotherapy for other conditions?

It is possible that intra-articular cortisone injections that result in long-lasting relief of symptoms with minor or few side effects ${ }^{17,42,43}$ could decrease the need for systemic corticosteroids in the management of JRA.

Rheumatologists treating children with JRA must balance two opposing realities. First, prolonged corticotherapy will invariably cause adverse systemic and articular effects in a spec- trum of disease that does not carry the threat of mortality as, for example, malignancies do. Second, a patient not given aggressive treatment after unaggressive management is unsuccessful may suffer a lifetime of disability and functional impairment. Currently, laboratory data can identify those patients at greatest risk for destructive disease who should be treated more aggressively. However, this study suggests that after remission of the disease, noncorticotherapy would be preferred as a maintainance therapeutic strategy. Our statistical correlations raise the possibility that systemic corticotherapy may be a contributing factor in the intra-articular progression of the disease. However, differences in disease severity between the corticosteroid-treated and not-treated groups should be considered in the interpretation of our results.

\section{ACKNOWLEDGMENTS}

We are grateful to Júlia Fukushima and Creusa dal Bo for statistical analysis and Angela C. Lorio, ELS for editorial assistance.

Study supported in part by FAPESP (Fundação de Amparo à Pesquisa do Estado de São Paulo) grant - 95 / 1890-0 and presented as a poster at the SPR Scientific Assembly on May 14, 1999.
DORIA AS e col. - Correlação entre as alterações osteocondrais evidenciadas à ressonância magnética e a progressão da doença. Rev. Hosp. Clín. Fac. Med. S. Paulo 56(4): 107-114, 2001.
Objetivo: Determinar as consequiências do uso crônico de corticosteróides sistêmicos em crianças com artrite reumatóide juvenil através da avaliação dos efeitos osteocondrais à ressonância magnética.
Pacientes e métodos: Achados clínicos e imaginológicos (ressonância magnética) de 72 joelhos em 69 crianças com artrite reumatóide juvenil foram revisados. Trinta e quatro (49.3\%) pacientes fizeram uso prévio de cortico- 
terapia sistêmica (22 pacientes do sexo feminino; 12 pacientes do sexo masculino; idade média: 11.3 anos; duração média da doença: 5.9 anos; duração média da corticoterapia: 2.9 anos; dose média cumulativa de corticosteróides: $5000 \mathrm{mg}) ; 35$ (50.7\%) pacientes não haviam feito uso prévio de corticoterapia sistêmica (27 pacientes do sexo feminino; 8 pacientes do sexo masculino; idade média: 11.7 anos; duração média da doença: 5.3 anos).

Resultados: No grupo que recebeu corticoterapia sistêmica prévia (Grupo
I) a presença de alterações osteocondrais à ressonância magnética relacionou-se de uma forma estatisticamente significativa com longo tempo de duração da doença (>3.5 years; $\boldsymbol{P}<0.001)$. Tal relação não foi estabelecida no grupo de pacientes sem uso prévio de corticosteróides sistêmicos (Group II). Da mesma forma, não houve relação entre a dose média de corticosteróides e os achados à ressonância magnética.

Conclusão: É importante avaliar-se os efeitos intra-articulares a longo prazo do uso crônico de corticoterapia sistêmica em artrite reumatóide juvenil à ressonância magnética, uma vez que os efeitos colaterais de uma terapia agressiva não devem ser potencialmente mais deletérios às articulações que os efeitos do curso natural da doença.

DESCRITORES: Corticoterapia sistêmica. Artrite reumatóide juvenil. Crianças. Joelho. Ressonância magnética.

\section{REFERENCES}

1. SCHALLER JG - Juvenile rheumatoid arthritis. Pediatr Rev 1980; 2:163-174.

2. JACOBS JC - Juvenile rheumatoid arthritis. Pediatric Rheumatology for the Practitioner. New York, Springer, 1993. p. 231-359.

3. YULISH BS, LIEBERMAN JM, NEWMAN AJ et al. - Juvenile rheumatoid arthritis: assessment with MR imaging. Radiology 1987; 165:149-152.

4. HERVÉ-SOMMA CMP, SEBAG GH, PRIEUR AM et al. - Juvenile rheumatoid arthritis of the knee: MR evaluation with Gd-DOTA. Radiology 1992; 182:93-98.

5. GRAHAM TB, BLEBEA JS, GYLYS-MORIN V et al. - Magnetic resonance imaging in juvenile rheumatoid arthritis. Semin Arthritis Rheum 1997; 27:161-168.

6. LAMER S \& SEBAG GH - MRI and ultrasound in children with juvenile rheumatoid arthritis. Eur J Radiol 2000; 33:85-93.

7. UHL M, KRAUSS M, HERGET G et al. - The knee joint in early juvenile idiopathic arthritis. Acta Radiol 2001; 42:6-9.

8. MELO-GOMES JA - Problems related to systemic glucocorticoid therapy in children. J Rheumatol 1993; 20 (suppl 37):35-39.

9. BREWER EJ, BASS J, BAUM J et al. - Current proposed revision of JRA criteria. Arthritis Rheum 1977; 20 (suppl):195-199.

10. SAS Institute Inc., SAS/STATâ User's Guide, version 6 , $4^{\text {th }}$ edition, Cary, NC: SAS Institute Inc.,1989. v.1.
11. REED MH \& WILMOT DM - The radiology of juvenile rheumatoid arthritis. A review of the English language literature. J Rheumatol 1991; 18 (suppl 31):2-22.

12. GILKESON G, POLISSON R, SINCLAIR H et al. - Early detection of carpal erosions in patients with rheumatoid arthritis: a pilot study of magnetic resonance imaging. J Rheumatol 1988; 15(9):13611366.

13. SENAC MO JR., DEUTSCH D, BERNSTEIN BH et al. - MR imaging in juvenile rheumatoid arthritis. Am J Rheumatol 1988; 150:873878 .

14. OSTERGAARD M, STOLTENBERG M, HENRIKSEN O et al. Quantitative assessment of synovial inflammation by dynamic gadolinium-enhanced magnetic resonance imaging. A study of the effect of intra-articular methylprednisolone on the rate of early synovial enhancement. Br J Rheumatol 1996; 35:50-59.

15. OSTERGAARD M, STOLTENBERG M, GIDEON P et al. - Changes in synovial membrane and joint effusion volumes after intraarticular methylprednisolone. Quantitative assessment of inflammatory and destructive changes in arthritis by MRI. J Rheumatol 1996; 23:1151-1161.

16. EICH GF, HALLÉ F, HODLER J et al. - Juvenile chronic arthritis: imaging of the knees and hips before and after intraarticular steroid injection. Pediatr Radiol 1994; 24:558-563.

17.HUPPERTZ HI, TSCHAMMLER A, HORWITZ AE et al. Intraarticular corticosteroids for chronic arthritis in children: efficacy and effects on cartilage and growth. J Pediatr 1995; 127(2):317-321 
18. WALLACE CA \& LEVONSON JE - Juvenile rheumatoid arthritis: outcome and treatment for the 1990s. Rheum Dis Clin North Am 1991; 17(4):891-905

19. WILSKE KR \& HEALEY LA - Challeging the therapeutic pyramid: a new look at treatment strategies for rheumatoid arthritis. J Rheumatol 1990; 17: 4-7.

20. JULKUNEN H, ROKKANEN P \& LAINE H - Chloroquine treatment and bone changes in rheumatoid arthritis. Scand J Rheumatol 1976; 5:36-38.

21. WRIGHT V \& AMOS R - Do drugs change the course of rheumatoid arthritis? Br Med J 1980; 280:964-966.

22.BROOK A, FLEMING A \& CORBETT M - Relationship of radiological change to clinical outcome in rheumatoid arthritis. Ann Rheum Dis 1977; 36:274-275.

23. DE CARVALHO A \& GRAUDAL H - Relationship between radiologic and clinical findings in rheumatoid arthritis. Acta Radiol [Diagn] (Stockholm) 1980; 21:797-802.

24. SHARP JT, LIDSKY MD, COLLINS LC et al. - Methods of scoring the progression of radiologic changes in rheumatoid arthritis: correlation of radiologic, clinical and laboratory abnormalities. Arthritis Rheum 1971; 14:706-720.

25. COHEN PA, JOB-DESLANDRE CH, LALANDE G et al. - Overview of the radiology of juvenile rheumatoid arthritis (JIA). Eur J Radiol 2000; 33:94-101

26. EMPIRE Rheumatism Council - Multi-centre controlled trial comparing cortisone acetate and acetyl salicylic acid in the longterm treatment of rheumatoid arthritis: results up to one year. Ann Rheum Dis 1955; 14:353-370.

27.EMPIRE Rheumatism Council - Multi-centre controlled trial comparing cortisone acetate and acetyl salicylic acid in the longterm treatment of rheumatoid arthritis: results of three years' treatment. Ann Rheum Dis 1957; 16:277-289.

28. JOINT COMMITTEE of the Medical Research Council and Nuffield Foundation on Clinical Trials of Cortisone, A C.T.H., and other Therapeutic Measures in Chronic Rheumatic Diseases - A comparison of cortisone and aspirin in the treatment of early cases of rheumatoid arthritis. Br Med J 1954; 1:1223-1227.

29. EMPIRE Rheumatism Council - A comparison of cortisone and aspirin in the treatment of early cases of rheumatoid arthritis. Br Med J $1955 ; 2: 695-700$.

30. JOINT COMMITTEE of the Medical Research Council and Nuffield Foundation on Clinical Trials of Cortisone, A C.T.H., and other Therapeutic Measures in Chronic Rheumatic Diseases - Long-term results in early cases of rheumatoid arthritis treated with either cortisone or aspirin. Br Med J 1957; 1:847-850.
31. JOINT COMMITTEE of the Medical Research Council and Nuffield Foundation - A comparison of prednisolone with aspirin or other analgesics in the treatment of rheumatoid arthritis. Ann Rheum Dis 1959; 18:173-188.

32. O'SULLIVAN MM, RUMFELD WR, JONES MK et al. - Cushing's syndrome with suppression of the hypothalamic-pituitary-adrenal axis after intra-articular steroid injections. Ann Rheum Dis 1985; 44:561-563.

33. SPARLING M, MALLESON P, WOOD B et al. - Radiographic followup of joints injected with triamcinolone hexacetonide for the management of childhood arthritis. Arthritis Rheum 1990; 33(6):821-826.

34. RUDDY S - The management of rheumatoid arthritis. In: KELLEY WN, HARRIS ED Jr., RUDDY $S$ et al. eds. Textbook of Rheumatology. Philadelphia, Saunders, 1981. p. 1000-1014

35. LIGHTFOOT RW Jr. - Treatment of rheumatoid arthritis. Arthritis and allied conditions: A textbook of rheumatology. Philadelphia, Lea, 1979. p. 513-518.

36. BUNCH TW \& O'DUFFY TD - Disease-modifying drugs for progressive rheumatoid arthritis. Mayo Clin Proc 1980; 55:161179.

37. ELLMAN P, LAWRENCE JS \& THOROLD GP - Gold therapy in rheumatoid arthritis. Br Med J 1940; 2:314-316.

38. IANNUZZI L, DAWSON N, ZEIN N et al. - Does drug therapy slow radiographic deterioration in rheumatoid arthritis? N Engl J Med 1983; 309(17): 1023-1028.

39. RASKER JJ \& COSH JA - Radiological study of cervical spine and hand in patients with rheumatoid arthritis of 15 years' duration: an assessment of the effects of corticosteroid treatment. Ann Rheum Dis 1978; 37:529-535.

40. MEIKLE JAK \& WILKINSON M- Rheumatoid involvement of the cervical spine. Ann Rheum Dis 1971; 30:154-161.

41. SMITH P, BENN RT \& SHARP J - Natural history of rheumatoid cervical luxations. Ann Rheum Dis 1972; 31:431-439.

42. ALLEN RC, GROSS KR, LAXER RM et al. - Intraarticular triamcinolone hexacetonide in the management of chronic arthritis in children. Arthritis Rheum 1986; 29:997-1001.

43. EARLEY A, CUTTICA RJ, MCCULLOUGH C et al. - Triamcinolone into the knee in juvenile chronic arthritis. Clin Exp Rheumatol $1988 ; 6: 153-155$.

Received for publication on November 20, 2000 